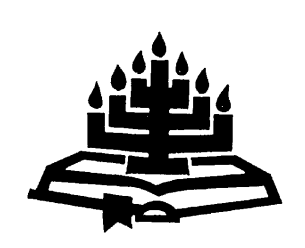

\title{
Die buitengewone geboorte van Jesus Christus en die regering van sy kerk, in die besonder rakende die vrou
}

\author{
J.L. Helberg (emeritus) \\ Skool vir Bybelwetenskappe \& Bybeltale \\ Potchefstroomkampus \\ Noordwes-Universiteit \\ POTCHEFSTROOM \\ E-pos: jaapjlh@absamail.co.za
}

\begin{abstract}
The extraordinary birth of Jesus Christ and the reign of his church, especially regarding women
\end{abstract}

The issue whether there is room for women in the special services of the church, especially as elder, is currently coresponsible for tension within the Reformed Churches in South Africa (RCSA). The ruling task of the church is closely linked with the way God rules his people and with what the relation between Him and his people is. The book of Matthew shows that there is an essential unity but also a drastic difference between the Old Testament and the New Testament dispensations in this regard. This article investigates at what dominates both dispensations and how they differ concerning this. Sin disrupted humanness and harmony fundamentally and in the most intimate relations. In the old dispensation power was inter alia exercised by force, for example in slavery and disregard of women's full humanness. The birth of Jesus Christ through the Holy Spirit from a woman without a man is the fulfilment of the Old Testament promises. All believers without difference in class or gender are recreated by Jesus Christ as the image of God and are reinstated in a personal relation with Him. Exercise of power over others, like in male domination of women and in earthly kingship and slavery makes room for being serviceable. Jesus Christ exercises his authority in a serving way. Especially his church must rule in a serving way by acknowledging Him as Head and testifying about his life, death and resurrection as contained in his Word. A believing woman is just as well equiped for this as a man. 


\section{Opsomming}

\section{Die buitengewone geboorte van Jesus Christus en die regering van sy kerk, in die besonder rakende die vrou}

Die vraag of daar volgens die Skrif vir die vrou in die besondere dienste plek is, veral as ouderling, is tans medeverantwoordelik vir spanning in die Gereformeerde Kerke in Suid Afrika. Die regeertaak van die kerk hang ten nouste saam met die manier waarop God sy volk regeer en met die verhouding tussen Hom en sy volk. Matteus wys dat daar in hierdie opsigte 'n wesenlike ooreenkoms, maar ook 'n ingrypende verskil tussen die OuTestamentiese en die Nuwe-Testamentiese bedelings is. Hierdie artikel ondersoek wat hieroor in albei bedelings dieselfde is, maar ook waarin hulle van mekaar verskil. Die sonde het menswees en harmonie tot in die intiemste verhouding grondig versteur. Heerskappy is in die ou bedeling onder meer deur dwang uitgeoefen, soos in slawerny en die miskenning van die vrou se volle menswees. Die geboorte van Jesus Christus deur die Heilige Gees uit 'n vrou sonder die toedoen van 'n man, is die vervulling van Ou-Testamentiese beloftes. Alle gelowiges, sonder onderskeid in stand of geslag, word deur Jesus Christus as beeld van God herskep en in 'n direkte persoonlike verhouding met Hom herstel. Heerskappyvoering oor ander, soos in die manlike dominering oor die vrou en in die aardse koningskap en slawerny, maak plek vir diensbaarwees. Jesus Christus oefen sy volmag dienend uit. Veral sy kerk moet dienend regeer deur Hom as die enigste Hoof te erken en van sy lewe, dood en opstanding te getuig soos dit in sy Woord vervat is. Daarvoor is 'n gelowige vrou net so goed toegerus soos 'n man.

\section{Inleiding}

Die vraag of daar volgens die Skrif in die besondere dienste vir die vrou plek is, veral as ouderling, is tans medeverantwoordelik vir spanning in die Gereformeerde Kerke in Suid Afrika (GKSA) (Van Wyk, 2008:6-7; Breed et al., 2008:13, 199-206; vgl. die Addendum vir 'n kort evaluering van laasgenoemde boek; vgl. Küng, 2005:61103 vir die onderlinge meningsverskille in Rooms-Katolieke en Protestantse kringe onderskeidelik). Die regeertaak van die kerk hang ten nouste saam met die manier waarop God sy volk regeer en met die verhouding tussen hom en sy volk. Matteus, veral die geslagsregister en geboortegeskiedenis van Jesus Christus, wys dat daar in hierdie opsigte 'n wesenlike ooreenkoms maar ook 'n ingrypende verskil tussen die Ou-Testamentiese en die NuweTestamentiese bedelings is (vgl. ook Peels, 2007:29-30 daarin dat rekening gehou moet word met die gang van die heilsgeskiedenis, 
met die ander aard van die nuwe bedeling in Christus en met die totaliteitsverhaal van die Bybel; vgl. verder Breed et al., 2008:42 oor die tydgerigtheid maar nie tydgebondenheid nie van die Bybel). Matteus 1 dui die geboortegeskiedenis aan as die vervulling van die Ou-Testamentiese verkondiging $(1: 22-23 ; 2: 6,15,18)$. Hierdie artikel fokus daarop hoe die regering van God albei bedelings beheers en waarin sy regering in die twee bedelings van mekaar verskil. Hier word dus 'n openbaringshistoriese en 'n koninkryksbenadering gevolg.

\section{Die geslagsregister en geboorte van Jesus Christus}

Net soos die geslagsregisters in die Ou Testament, is die geslagsregister van Christus ook patriargaal, maar hier kom egter nie net die name van mans voor nie. Daar word ook na vier vroue verwys, naamlik Tamar, Ragab, Rut en Batseba, en natuurlik na Maria, die moeder van Jesus aan die einde. Verklaarders gee verskillende redes waarom hierdie vier vroue vermeld word, soos hulle twyfelagtige gedrag en hulle vindingryke optrede om hulle persoonlike situasies te beredder (Anderson, 1983:9; Levine, 1998:340; Niditch, 1998:17-29). Hierteenoor geld egter dat die fokus in Matteus 1 nie op menslike kreatiwiteit of prestasie gerig is nie, maar op die ingrypende optrede van God wat uit 'n doodloopgeskiedenis 'n heeltemal nuwe bedeling bewerk. Die geslagsregister verwys glad nie na wat die vroue gedoen het nie, maar sê telkens slegs dat " $X$ " die vader van "Y" by die betrokke vrou was. Batseba word selfs nie eens by die naam genoem nie, net Dawid en Uria. In al die gevalle is die fokus op die mans.

Al vier die vroue kom in die eerste deel van die geslagsregister, naamlik van Abraham tot Dawid, voor. Aan die einde van die derde geslagsregister kom Maria voor. Sy word nie genoem weens haar fisiese of geestelike kreatiwiteit nie. Die fokus val voluit op die skeppende krag van God en wat Hy in haar deur die Heilige Gees verwek (een Siriese teks lui wel anders; Van Bruggen, 1990:33). Daar is nie sprake van die Heilige Gees as seksuele deelgenoot van Maria nie (Matt. 1:16, 20; Floor, 1981:44; Hagner, 1993:17; Luz, 1985:101, 104).

Reeds die begin van die geslagsregister impliseer dat die verloop van die verbondsgeskiedenis deur God se buitengewone bemoeienis bepaal is. Die geslagsregister begin met Abraham, die vader van Isak. Uit die verbondsgeskiedenis is dit bekend dat God sonder verdienste van Abraham se kant die verbondspad met hom geloop het. Abraham en sy vrou kon nie kinders hê nie. Tog het God gesorg 
vir die voortgang van die geslagslyn. Hy het Isak as 't ware uit die dood gebore laat word. Die gebeure word herhaal in die geskiedenis van Isak en Rebekka.

Die geslagsregister van Christus eindig op dieselfde noot, met die buitengewone geboorte van Christus. Nie die geslag, nasionaliteit, etiese voortreflikheid, vindingrykheid of kreatiwiteit van die draers van die linie bepaal die uitkoms van die gelowige geslagslyn nie, maar die reddende optrede van God wat die menslike denke en vermoëns transendeer. Persone wat 'n mens nie in die geslagslyn sou verwag nie, verskyn daarin. Ook vroue verskyn daarin, selfs vroue wat weens hulle karakter of nasionaliteit nie daarin verwag sou word nie. Maar geloofsmoeders soos Sara, ontbreek. Die eerste en tweede van die drie tydperke van die geslagsregister word albei deur die vermelding van vroue gekenmerk en hierdie twee tydperke word deur Batseba verbind. Die verrassende verloop van die geslagslyn bereik 'n klimaks aan die einde van die derde tydperk. Die patriargale aanbieding word deurbreek, die manlike skakelpersoon, Josef, word uitgeskakel en sy vrou, Maria, word in die geslagsregister ingeskakel.

Die geslagsregister van Israel, die volk van God, waarmee Matteus begin, loop uit op die situasie waarin Israel hulle in die tyd van Matteus bevind, naamlik onder vreemde heerskappy en as 't ware in 'n volksdood (vgl. Eseg. 37). Israel verwag 'n verlosser wat hulle met mag kan verlos, soos koning Dawid (Matt. 1:6); een wat die koninkryk van Israel kan herstel. Matteus kom egter met die verrassende verkondiging dat die eintlike behoefte aan 'n verlosser nie is om van daardie vyande verlos te word nie, maar van die vyand in Israel en die mens self, naamlik van hulle sonde! (Matt. 1:21; vgl. Floor, 1981:17-33; Helberg, s.a.:8-9 oor die persoonlike karakter van die koninkryk).

Israel se geslagsregister, en dus hulle geskiedenis, bereik sy hoogtepunt in "koning Dawid" (Matt. 1:6) - 'n situasie van mag en heerlikheid. Die hoogtepunt wys egter juis 'n probleem uit wat dwarsdeur die geskiedenis voorkom, naamlik magsmisbruik. Selfs Dawid is daaraan skuldig. Sy optrede het nie net met seksuele oortreding te doen nie, hy veroorsaak ook Uria se dood (2 Sam. 11).

Die verwagte Verlosser gaan nou juis die probleem van magsmisbruik aanpak. Mag en heerskappy oor ander gaan nie sy optrede beheers nie. Hy is (skynbaar) magteloos en Hy dien, soos gesien in die gebeurtenisse rondom sy geboorte, sy hele lewe en sy sterwe. Jesus word nie deur 'n man en manlike krag voortgebring nie, maar 
wel deur 'n (weerlose) vrou. Daarmee word 'n algehele nuwe begin met Israel (en die mensdom) se geskiedenis gemaak - een wat alleen deur wonderbaarlike Goddelike ingryping moontlik is. Israel se geskiedenis, wat dié van die hele mensdom verteenwoordig (Luz, 1985:97), loop dood. 'n Nuwe begin is nodig, geïnisieer van anderkant die aardse werklikheid af.

Matteus begin die geslagsregister van Christus nie met die voorIsraelitiese tydperk nie. Die rede daarvoor is dat hy Israel uit hulle eie geskiedenis wil oortuig dat Jesus die Christus, die beloofde Messias is. Dat Matteus wel deeglik met daardie voorgeskiedenis en die man se misbruik van die situasie reken, blyk uit sy antwoord oor die kwessie van egskeiding in hoofstuk 19:8: "Dit is oor die hardheid van julle harte dat Moses julle toegelaat het om van julle vroue te skei, maar dit was nie van die begin af so nie."

In die geslagsregister is die man, juridies gesien, die verteenwoordiger van die mensdom. Hy verteenwoordig daarom ook die sondelas wat die mens saamdra. Dat die man in Christus se geslagsregister by Josef verbygegaan word, wys dat Josef se vaderskap van Jesus Christus net juridies is (Ridderbos, 1995:2122; Van Bruggen, 1990:33; Hagner, 1993:18) en dat die sondelas nou juridies afgehaal word. Jesus Christus word sondeloos en as Seun van God gebore. Daarmee neem Hy die skuld van die sonde juridies op Hom en kan Hy sy volk (en die mensdom) van hulle sondes verlos. Tegelykertyd word met die gevolge van die sonde gebreek soos oorheersing oor 'n ander mens, veral oorheersing oor die vrou.

Nou word aangesluit by die vrou met haar nie-gerekende posisie in die geskiedenis. Behalwe dat die belofte van oorwinning wel met haar en haar ongenoemde dienende aandeel aan die gang gehou is, gaan sy nou deel hê aan die uiteindelike volle vervulling in Christus.

Deur hierdie volle vervulling is God by ons deur sy Seun wat nie deur uitwendige magsuitoefening kom nie, maar in swakheid. Hy is magteloos teen die vyandskap van Herodes en andere en Hy tree dienend en in liefde op. Sy koninkryk en heerskappy is ' $n$ ander soort as dié wat mense bedink. Hy oorheers sy volk nie met uitwendige magsmiddele nie, maar regeer oor hulle deur hulle harte te verander om Hom met vreugde te dien. So sal sy volk dan ook hulle medemens in hulle volle menswees, beeld-van-God-wees, erken en dien en nie oorheers nie. 


\section{Gebeurtenisse in die begin van die mens se geskiedenis}

Vooraan in die Bybel word God se absolute mag as skepper en regeerder van alle dinge gestel (Gen. 1-2; vgl. Bird, 2001:260 vir hierdie beginhoofstukke as deel van 'n literêre werk sowel as 'n inleiding tot die Bybelse geskrifte as 'n geheel). Reeds heel aan die begin van die mens se geskiedenis loop dinge egter skeef. In plaas daarvan om as beeld van God in onderworpenheid aan God te regeer, wil die mens self die norm en wet wees (Gen. 3). Nóg die man, nóg die vrou is tot seksuele optrede verlei, maar wel om outonoom te wil optree.

Dit boemerang op albei, maar die vrou word die ergste geraak. Sy word nie alleen deur die man se onpersoonlike "outonome" optrede gedomineer en verslaaf nie, maar ook in haarself: "Na jou man sal jy hunker, en hy sal oor jou heers" (Gen. 3:16). Hierdie hunkering is nie bloot of selfs eerstens vir seksuele omgang nie, maar vir die diepste behoefte van menswees, in-verhouding-wees (en vir die mens of kind wat daaruit voortvloei).

Die benadering dat die vrou volgens Genesis 3:16 na die heersersposisie van die man sal hunker (Breed et al., 2008:70-71), impliseer dat sy blatant in haar verkeerde optrede volhard het. Daarvoor ontbreek steun in die teksverband. Daardie benadering hang saam met die gedagte van hoofskap en "ongelykheid". Die punt waarom dit gaan, is egter dat Adam nie sy mede-verantwoordelikheid saam met die vrou nagekom het nie. Nóg Adam, nóg Eva het erns daarmee gemaak dat die mens in homself net stof is en alleen ' $n$ harmoniese verhouding met God, met mekaar en met die skeppingswerklikheid kan hê as hulle God se absolute soewereiniteit erken (Gen. 3:8-11, 17-19). Die "ongelykheid" wat Breed et al. (2008:70) aan die vrou se posisie toeskryf, moet eerder soos die leidinggewende rol van Petrus as eerste onder die gelykes gesien word (Matt. 16).

By die man is die begeerte van in-verhouding-wees swakker as by die vrou en is die aandag sterker op homself in hierdie verhouding gerig. Daarom verwyt hy die vrou makliker vir die situasie waarin hulle saam beland het. Albei skuif die verantwoordelikheid hiervoor van hulleself af, maar die vrou kyk hiervoor na iemand buite die eie intieme kring.

Die man word in sy meer onpersoonlike benadering getref en sal veral in sy werksomstandighede swaar kry. Die vrou word veral in 
haar meer persoonlike, of verhoudingsgerigte benadering getref. Die man benader sake, die lewe en die vrou ook meer outonoom en selfgerig. As hy die vrou beken, is sy dryfveer nie net om 'n persoonlike omgang met haar te hê, soos die woord impliseer nie (Schottroff, 1971:691; vir die persoonlike verhouding in jada vervat, vgl. ook Weiser, 1959:70-71; Kraus, 1972:9. Ridderbos, 1955:17 praat van 'n ken in liefde). Hy wil beheer oor haar uitoefen (Gen. 3:16).

Die vrou en wat in haar verwek word, is in die man se beheer, soos sy besittings (vgl. ook haar plek in die vierde en die tiende gebod; in die geheel gesien was 'n vrou, hoewel gerespekteer in die $\mathrm{Ou}$ Testament, geag as ' $n$ mindere in vergelyking met 'n man; De Vaux, 1968:39-40; Breed et al., 2008:72,74). Dit gaan om sy nageslag soos uitgedruk in die manlike dominering in die geslagsregisters. Aan die begin van die verloop van die geskiedenis wat volg, kom die vrou nog ter sprake in die teleurstelling en hoop in verband met die kinders: Kain en Abel/Set (Gen. 4). In die menslike geslagsregister van Genesis 5 word "seuns en dogters" genoem, maar sy word nie genoem nie, behalwe in die begin, wat baie belangrik is.

Die ondergeskiktheid van die vrou word deur Rodd (2001:250-257) en andere nie as 'n gevolg van die sondeval gesien nie, maar bloot as vrug van die patriargale of androsentriese kultuur van die $\mathrm{Ou}$ Testament. Hierdie benadering neem egter nie Genesis 3:16 ernstig op nie.

Die man se selfsugtige en dominerende optrede teenoor die vrou is net die eerste linie van sy optrede teenoor sy medemens in die geheel. Dit loop verkeerd met die mensdom, soos blyk uit Kain se optrede en dié van Lameg in sy veelwywery en sy wraaklied wat hy vir sy vroue sing (Gen. 4). Outonome magsoptrede bied egter nie 'n oplossing nie, maar loop uit op korruptheid en ondergang (vgl. die sondvloed, Gen. 6-8).

Vir die skrywer van Genesis 3 lê die oplossing daarin dat lewe voortgaan. Direk na die strafaankondiging oor die mens, wat eindig met die aankondiging van die dood oor die mens, volg die woorde oor lewe (Gen. 3:20): "Die mens het sy vrou Eva (= lewe) genoem; sy was die moeder van al die mense." Die woorde volg onverwags en in sterk teenstelling met die strafaankondiging oor dood. Al sou hierdie woorde oorspronklik tot 'n ander bron behoort het (Westermann, 1974:364), maak dit vir ons onderwerp nie 'n verskil nie. Teen die verloop van sake in, teenoor die mens se optrede wat tot die dood in al sy gestaltes van disharmonie in alle verhoudings 
en optrede lei (Helberg, s.a.:37), laat God in sy opsoekende genade en onvernietigbare liefde tog die lewe voortgaan. Die heerssug van die man word aan bande gelê deur voorskrifte vir die geloofsgemeenskap (Breed et al., 2008:72-74). Die feit dat die mens nog lewe, is reeds ' $n$ teken van God se genade (Brueggemann, 1982:4950). Hierdie aardse bestaan is nou wel erg aangetas, maar die mens staan selfs in hierdie situasie in 'n verbondsverhouding met God (Gen. 9:8-17; Brueggemann, 1997:453-454).

\section{Betekenis van die geslagsregister in die begingeskiedenis}

Die mens se geslagsregister (Gen. 5) weerspieël sy bestaan en geskiedenis (Westermann, 1974:470; vgl. ook Holwerda, 1971:15 oor toledot en die weldeurdagte komposisie van Genesis). Die geslagsregister teken die mens se stryd om oorlewing, maar tegelyk ook die genadige sorg van God (vgl. Van Selms, 1967:94 vir toledot adam as aanduiding vir die mensdom hier). Die geslagsregister sluit aan by die gebeurtenis in die tuin van Eden. In die geslagsregisters speel die vrou 'n ondergeskikte rol hoewel sy in haar menswees en haar verhouding met God gelyk is aan die man. Haar ondergeskikte rol is volgens Genesis 3 die gevolg van die sonde in die tuin, maar ondanks die sonde en die straf daarop is man en vrou nog albei beeld van God (Gen. 5:1-2; Von Rad, 1966:69). Die vrou se beeldvan-God-wees, haar volle menswees in verhouding met God en haar man, is ernstig versteur, maar word tog nog erken en gehandhaaf (Van Selms, 1967:94; Westermann, 1974:482).

Volgens Genesis 1:26-28 is die man en die vrou nie saam beeld van God nie, maar elkeen afsonderlik: "As beeld van God het Hy die mens (letterlik "hom", enkelvoud) geskep, man en vrou het Hy hulle (meervoud) geskep" (vgl. ook Breed et al., 2008:69). As enkelinge is man of vrou nie net 'n halwe beeld van God nie, maar elkeen is volledig beeld, volledig mens. Die voortplantingsmoontlikheid van die mens is deur die skrywer van Genesis 1 versigtig verwyder van die mededeling oor God se beeld na 'n spesiale woord oor seën (Von Rad, 1966:59). God is bo seksualiteit verhewe, anders as die heidense gode. Die gelowiges aanbid God in die wete dat "vader" en "koning" menslike taal is en ontoereikend is om die volle werklikheid van God uit te druk (Childs, 1986:40; vgl. ook Westermann, 1974:282).

Dat God die mens in twee geslagte geskep het, wys ook dat die mens nie 'n blote enkeling is nie, maar ' $n$ gemeenskapswese 
(Westermann, 1974:221; vgl. ook Breed et al., 2008:69). God hou die mens nog onder sy sorg. Van die heel begin af het God vanself die mens se behoefte in gedagte gehou en geoordeel dat dit nie goed is dat die mens alleen is nie. Daarom het God in die mens se behoefte voorsien deur uit homself 'n vrou te vorm, 'n helper, 'n gelyke (Gen. 2:20). Die mens ontvang haar met vreugde as: "een uit myself, een soos ek. Daarom sal sy vrou/mannin genoem word, sy is uit die man geneem" (Gen. 2:23). Ook sy is voluit mens, net in vroulike vorm (isja). Die beskrywing van die mens in Genesis 1:2628 en 2:6-25 is dus wesenlik dieselfde. Hoewel die vrou uit 'n deel van die mens gemaak is (Gen. 2:21), het sy nie uit die man gegroei nie, maar is sy deur God gemaak, net soos die man. Die man speel daarin geen aktiewe rol nie, maar verkeer in 'n diepe slaap wanneer dit gebeur. God se verhouding tot die vrou is wesenlik soos dié teenoor die man. Sy het 'n direkte verhouding met God, nie indirek, deur die man nie.

Die oorweging om vir die man 'n helper (ezer) te kry (Gen. 2:18), dui nie daarop dat die persoon 'n mindere is nie, maar wel 'n gelyke (kenegdo). God word in die psalms 'n helper genoem (Ps. 10:14; $30: 11 ; 54: 6)$. Die feit dat die mens sy vrou benoem, wys hier ook nie op heerskappy soos by die naamgewing aan die diere nie (kontra Breed et al., 2008:70). Hier word die eenheid aangedui wat nie tussen die mens en die dier gevind kan word nie, maar net uit die mens self (Kroeze, 1967:37). Die man en die vrou is wel op mekaar aangewese. Hulle verhouding tot mekaar word bepaal deur hulle verhouding met God. As dit positief is, is daar harmonie. Daarom skaam hulle hulle nie, al is hulle naak (Gen. 2:25). Die harmoniese verhouding tussen man en vrou verdwyn wanneer die mens nie as beeld van God optree nie, dit wil sê nie in die nouste persoonlike verhouding met God optree en sake en persone so benader en beoordeel nie.

Die mens het nie betekenis in homself nie, maar alleen in sy verhouding met God. Hy is die verteenwoordiger van God, soos 'n beeld iemand verteenwoordig, of 'n skaduwee iets verteenwoordig (Van Selms, 1967:35-36 sien 'n verband tussen beeld [tsêlem] en skaduwee [tsel]). Die mens is as beeld van God onder heerskappy van God (Bird, 2001:260).

Veral die vrou word nadelig getref as sy nie as die beeld van God optree nie. Net wanneer sy haarself in verhouding met God sien en sodanig optree, of deur ander so benader word, kom sy tot haar reg as mens. Anders kom sy kronologies én wesenlik ná die man en is sy ondergeskik aan hom, synde ná hom en úit hom. Soos die mens 
net grond is as hy nie gesien word in sy verhouding met God wat hom sy besondere posisie as regeerder besorg nie (Ps. 8:4-5), so is sy dan ook net grond en uit die man. Nie 'n mens se geslagtelikheid bepaal jou kwaliteit as mens nie, maar jou verhouding met God. Geslagtelikheid is wel belangrik vir die uitoefening van die onderskeie roepings en die verantwoordelikhede van die man en die vrou. Genesis 1 en 2 saam gelees, sluit enersyds die beskouing uit dat die vrou onderhorig is aan die man, en andersyds dat albei geslagte presies eners is (Childs, 1986:188-194).

Dit is blykbaar in hierdie lig wat Paulus se benadering oor die "skeppingsprimaat van die man" verstaan moet word. 1 Korintiërs 11:8-9 lui: "Die man is nie uit die vrou geneem nie, maar die vrou uit die man. Die man is ook nie ter wille van die vrou geskep nie, maar die vrou ter wille van die man" (vgl. ook die opdrag dat die vrou in die byeenkomste moet stilbly, 1 Kor. 11:34). Skrifgedeeltes wat die vrou blykbaar aan die man ondergeskik stel, moet benader word uit hulle agtergrond (vgl. byvoorbeeld Marshall, 1999:437-443; Wolff, 1996:140,147) en in die lig van die verlossingsaankondiging in Matteus 1. Hierdie aankondiging beheers nie alleen die hele boek nie, maar die hele Nuwe Testament as vervulling van die Ou Testament (vgl. egter ook Grosheide, 1953:250-261).

Dit val buite die opset van hierdie artikel om in besonderhede hierop in te gaan. Daarom word met die volgende stelling volstaan: Dit gaan hier (1 Kor. 11:9-34 e.v.) blykbaar oor die geëmansipeerde vrou wat in selfgesentreerde magsug vir haarself gesag opgeëis het en daarmee haar man in die verleentheid gestel het. Dit is ook deur hierdie selfgesentreerdheid en magsug wat die vrou haar in die tuin van Eden laat verlei het (1 Tim. 2:14) om nie in die regte verhouding met God te leef nie, die verbod op die eet van die kennisboom verontagsaam het en nie 'n ware "helper" vir die man was nie. Die helperwees was nie bloot ter wille van die man bedoel nie, maar ter wille van die gesamentlike lewe-in-erkenning van God en sy gebod.

Al speel die vrou in die geslagsregisters 'n ondergeskikte rol, is dit tog 'n belangrike dienende rol. Die voortbestaan van die mens en later spesifiek van Israel, is aan haar verbind. Sy het die belofte ontvang dat in die vyandskap tussen haar saad of nageslag en die groot vyand, die slang, haar saad sal oorwin. Die geslagsregister hang dus saam met oorlewing, soos in Genesis 3:20 gesien. Die geloof in net een God het 'n sterk vertroue in die doelgerigtheid van God se regering van dinge en die mens gewek. Selfs in die moeilikste omstandighede is die hoop en toekomsverwagting wakker gehou. 
Geslagsregisters het ook die gedagte lewend gehou dat die loop van die geskiedenis nie deur menslike mag of moontlikhede bepaal word nie, maar deur God wat lewe gee. Die refrein "sterwe" in die geslagsregister in Genesis 5 word byvoorbeeld onderbreek deur: "Henog was nie meer daar nie, want God het hom na Hom toe weggeneem" (vgl. ook Abraham se geboorte en verder die feit dat die verbond nie deur enige vrou voortgaan nie, maar deur Sara aan wie sy belofte verbind is).

Die gedagte van 'n nuwe begin uit 'n doodsituasie kom dwarsdeur die Ou Testament voor en getuig van Goddelike inisiatief en optrede, as 't ware lewewekking uit dood. So laat God sy koninkryk kom (vgl. hieroor Helberg, s.a.:13 in verband met die tuingeskiedenis, sondvloed, roeping van Abraham, uittog uit Egipte, die rigters en konings wat uitloop op die ballingskap; Eseg. 37).

\section{Regering deur die koningskap en deur die Woord}

Die geslagsregister in Matteus werk op na "koning Dawid" as 'n hoogtepunt, maar van daar af volg dit 'n dalende lyn en eindig as 'n doodlooppad (Hagner, 1993:12). God werk daarom deur geboorte, deur te verwek. Daardeur word die lewe ondanks die dood, wat in die geslagsregister aangedui word, voortgesit. Matteus 1:22-23 verbind hierdie gebeurtenis met die Immanuel-profesie van Jesaja 7:14. Die oplossing vir die vervreemding met God lê veral in God se by-ons-wees deur sy heerskappy en die mens se geloofsverhouding met Hom.

Die geboorte van Jesus Christus is die vervulling van wat "die Here deur sy profeet" hieroor "gesê het" (Matt. 1:22). Matteus sluit hier aan by Jesaja 7:14, maar noem nie Jesaja nie, want Jesaja verteenwoordig die hele profesie (Ridderbos, 1995:15-16). Dat God by ons is, is die kern van die profete se verkondiging (vgl. byvoorbeeld ook Jes. 41:13, 14; 43:1-5; 44:8; Jer. 30:10-11).

Deur Christus bring God op 'n wonderbaarlike manier sy belofte tot vervulling en laat Hy die mens terugkom na Hom toe. 'n Mens kom na Hom toe deur sy Woord, soos die verwysings na die Woord reeds in die geboortegeskiedenis van Jesus en daarrondom wys (Matt. 1:22, 23; 2:6, 15, 18). Hierdie belangrike betekenis van die Woord word ook in die opset van die psalms na vore gebring, deurdat die Woord voor die koningskap (Ps. 2), heel vooraan geplaas word (Ps. 1; Tora het hier die engere sowel as wyere betekenis van Wet en Woord). Die Woord as beheersende saak in 
Psalm 1 beheers die hele psalmbundel (Helberg, 2005:674-680; Childs, 1979:513; vgl. ook Weber, 2006).

Die koning van wie hier gepraat word, sal meer wees as Israel se koning. Psalm 2 as inleiding plaas die hele bundel in 'n messiaanse lig (Mitchell, 1997:88-89). Hierdie koning sal die aard van die koningskap wat in die volk van God, in Israel, en veral in Dawid tot vergestalting gekom het, verander. Hy sal die klem laat verskuif van 'n aardse magsuitoefening na diensbaarheid in algehele oorgawe aan God deur die Wet/Woord as lewensbron (Ps. 1).

In teenstelling met die mitologie by ander nasies reken die psalms met 'n God wat in 'n persoonlike erkenning onmiddellik aangeroep en ervaar kan word omdat Hy Hom onmiddellik in die Wet geopenbaar het (Kratz, 2003:153, 155-156). Die Woord regeer die mens van binne uit, en is primêr. Psalm 1 benader die verhouding met God en daarmee samehangend die verhouding met mense, nie vanuit nasionaliteit of sosiale stand nie, maar eties-religieus (Rogerson, 1993:293; Sheppard, 1991:72). Die teenstelling is tussen regverdiges (gelowiges) en goddeloses (dié wat hulle nie aan God se wil steur nie, maar hulle eie wil laat geld en daarom ander mense verontreg). Dit gaan dus in die regering deur die Woord nie om die mens se manwees of vrouwees nie, maar om die verhouding met God en sy Woord.

Die profete verwag 'n herskepping van die menslike hart (Jer. 31:3134; vgl. Keel, 1997:306 oor Ps. 51:10-11). Jesaja 40 praat oor die mag van God, oor die krag van sy Woord en sy sorgende teenwoordigheid en oor sy dienaar wat dienend sal optree vir sy volk asook vir die nasies en wat selfs gewillig vir hulle sal ly (Jes. 42:6; 52:13-53:12).

Met Christus as vervulling kom daar nou 'n nuwe en andersoortige bedeling. Volgens sy geboortegeskiedenis en sy prediking is Hy die nuwe en andersoortige Koning. Die koningskap van Israel, 'n vergestalting van mag en heerlikheid, is uitgedien, en die regering gaan met Christus ' $n$ nuwe bedeling in. Koningskap is trouens ' $n$ laatkommer in Israel se geskiedenis. Teen die tyd van sy verskyning was al die basiese faktore vir volk-van-God-wees, reeds daar. Die messiasskap is wel sterk aan Dawid en die koningslyn verbind, maar die koningskap kon verdwyn sonder wesenlike verlies vir Israel se geloof en volksbestaan. Tog was die oorgang na 'n nuwe bedeling nie maklik nie. Israel het nog sterk vasgehou aan 'n aardse koning en aardse manier van regering vir die volk van God. Christus 
se koningskap en manier van regeer was nie vir hulle aanneemlik nie en Hy is uiteindelik selfs gekruisig.

\section{Die ingrypende verandering wat die koms van Jesus Christus en die koninkryk volgens sy prediking meebring}

Die koms van Christus vra 'n omwenteling by Israel (en die mensdom as 'n geheel). Die sonde, waarvan Jesus sy volk kom verlos, sit diep en vra 'n ommekeer in mense se benadering en lewe. Vir Jesus en Johannes die Doper is bekering onafskeidelik verbind aan die koms van die Koninkryk (Matt. 3:2; 4:17).

Hierdie radikale betekenis van Christus se koms kom ook duidelik uit in sy bergrede (Matt. 5-7). Wat Hy vra en gee, gaan veel dieper as wat die mens bedink en doen. Dié wat van die koninkryk is, benader sake nie vanuit 'n magsposisie nie, maar vanuit die besef van "hoe afhanklik hulle van God is" (Matt. 5:3). Dit is trouens uit daardie gesindheid wat Christus self opgetree en uiteindelik gesterf het en so God se manier om die Koninkryk te laat kom, gedien het. Sy aandeel en die aandeel van dié wat in Hom glo, is om te dien. Hierdie benadering beheers die hele evangelie. God laat self sy koninkryk kom. Juis die mense wat blykbaar geen toekoms het nie, sal die koninkryk van die hemele, dit is volle bevryding, ontvang. God sal vir hulle intree as Koning, die onderhouer van geregtigheid wat veral 'n oop oog het vir die lot van die onderdrukte.

Christus het self uitdruklik gesê dat sy radikale eis nie van die wese van die Ou Testament verskil nie; Hy het nie "gekom om die wet of die profete ongeldig te maak nie ... maar om hulle hulle volle betekenis te laat kry" (Matt. 5:17). Getrouheid aan die wet vereis nie bloot dat 'n mens na die letter kyk nie, maar dat jy op persoonlike toewyding aan God fokus - anders wil jy die wet in jou eie greep hê en tot jou eie voordeel heerskappy oor ander uitoefen. Vir Christus gaan dit nie om 'n onpersoonlike benadering, soos in "'n oog om 'n oog", waarin geregtigheid onpersoonlik afgemeet word nie, maar om 'n onvoorwaardelike en persoonlike verhouding van liefde. Daarin ag die een die ander hoër as homself. Dan het jy nie net dié lief wat vir jou liefhet nie, maar selfs jou vyande! (Matt. 5:43, 44).

Die gebed wat Christus sy gelowiges geleer het, benadruk enersyds die absolute heerskappy en gesag van God en andersyds die noue persoonlike verhouding met God. Dit is die eerste gebed in die Bybel waarin God as Vader aangeroep word. Hoewel God in die Ou Testament soms as Vader beskryf word, word Hy tog nie in gebed 
so aangeroep nie. Christus het daardie weg na God heeltemal oopgemaak. Die gelowige is deur Christus weer voluit beeld van God (Rom. 8:29; 2 Kor. 3:18). Almal kan hierdie gebed so bid. Ook vir die vrou is God op 'n direkte manier Vader, nie eers deur manlike bemiddeling nie.

\section{Die belydenis van Petrus oor Jesus Christus en sy gesag}

Petrus bely Jesus as "die Christus, die Seun van die lewende God" (Matt. 16:16). Hierdie belydenis is nie aan hom bekend gemaak deur die menslike natuur nie, maar deur 'n openbaring van God (Matt. $11: 27 ; 16: 17)$. Hoewel alleen Petrus genoem word, is hierdie gesag ook aan die ander apostels (Joh. 20:21-23) en aan die kerk self gegee (Matt. 18:18-20; Ridderbos, 1995:303; Floor, 1981:69). Christus self bou sy kerk, sê Hy in sy volgende woorde. Die dissipels is die fondament as gevolg van hulle getuienis oor Hom.

In die evangelies is dit die eerste en enigste plek waar Christus van sy kerk praat, behalwe in Matteus 18:17. Hy gebruik 'n woord wat ooreenstem met die naam van ou Israel as 'n religieuse gemeenskap (Hebr. Qahal). Die volk van die Messias gaan Israel as die volk van God vervang. Die kerk van Christus sal nie deur die mag van die dood oorweldig word nie, want Christus is sterker as die dood en sal sy kerk in staat stel om in sy oorwinning daaroor te deel, hoe swak die kerk ook al mag skyn te wees (Ridderbos, 1995:304-305).

Christus gee aan hulle die "sleutels van die koninkryk van die hemel". Hierdie gesag is nou verbind aan die fundering van die kerk, want die kerk is die gemeenskap van dié wat die koninkryk verwag en sy verlossing ontvang. Sy dissipels moes hierdie gesag uitoefen in voortdurende onderwerping aan Hom. Hulle moes onderrig, dit is om met Goddelike gesag te praat oor hoe iemand in die koninkryk kan ingaan, en hulle moes regeer deur toesig te hou oor die kerk in ooreenstemming met hulle lering (Ridderbos, 1995:305-306). Hulle moes nie self heers nie, maar die gesag van Christus bedien.

Die dissipels het min verstaan van die ware aard van die koninkryk wat met Christus aangebreek het en van sy dienende soort magsuitoefening en regering oor veral sy volk van gelowiges. In die dissipels se verwagtings was daar nie plek vir 'n sterwe en opstanding van Christus nie. Direk na Petrus se belydenis verset hy hom teen so 'n gedagte (Matt. 16:21-23). Christus reageer skerp op hierdie wanbegrip van Petrus en noem hom 'n instrument van Satan wat nie dink aan wat God wil hê nie, maar aan wat mense wil hê. Hierdie 
gebeure herinner aan hoe die mens in die tuin van Eden deur Satan verlei is om God se regering verkeerd te benader en wat toe op die dood uitgeloop het. Hier gee Christus nou die versekering dat Hy sy volk nie deur die magte van die doderyk sal laat oorweldig nie.

Nou, by die wesenlik belangrike gebeurtenis in verband met die sleutels tot die koninkryk, is dit nie 'n vrou (of die vrou) deur wie die verleiding kom nie, maar die rotsman onder die dissipels. Nie manlikheid of vroulikheid is vir verleiding oor die koninkryk vatbaar nie, maar menslikheid. Dit is ewe-eens nie manlikheid of vroulikheid wat die koninkryk in stand hou of die toegang daartoe bepaal of beheer nie, maar Christus self. Petrus se wanbegrip oor hoe die koninkryksregering werk, sit diep en word herhaal wanneer Jesus se optrede nie op magsuitoefening uitloop nie, maar op die kruisiging. Dan verloën Petrus Hom (Matt. 26:31-35).

Die kerk moet die sleutels van die koninkryk dus nie as 'n magsuitoefening benader nie, maar as 'n dienfunksie. Vroeg in die geskiedenis het die kerk egter eersgenoemde pad gekies. Die Hervorming het hiermee gebreek en Christus as die enigste hoof van die kerk gesien. Ondanks die Hervorming is die mag egter dikwels in menslike hande gehou (Du Plooy, 1982:76; Spoelstra, 2007:27-29, 39).

Met die Woord moet ons verder deurtas. Gelowiges het 'n dienende verantwoordelikheid om dié wat deur die vervulling deur Christus vrygemaak is, in hulle koningwees, priesterwees en profeetwees tot hulle reg te laat kom. God het trouens nie ampsdraers soos konings, ensovoorts geskep nie, maar elke mens in sodanige hoedanigheid (Gen. 1:26-28).

Bediening van die sleutelmag beteken om die Woord aan die woord te laat kom en wel so dat die dienende aard van Christus en sy regering oor sy kerk daarmee bedien word. Bedien beteken nie om 'n hef in die hand te hou deur nog Goddelike ampsgesag buite die gesag van die Woord en die Gees vir pous, ouderling of predikant op te eis nie. Die volle klem moet op die Woord en Gees as die setel en bron van die gesag val. Die kern van die verkondiging is die dienende aard van Christus, vergestalt in sy sterwe en opstanding.

Dit gaan dus nie om heers nie, maar om die bediening van die mag van Christus. Om hierdie sleutels te hanteer vra dus nie een of ander hiërargiese mag of geslagtelike hoedanigheid nie. Die vrou se aandeel in die geslagsregister van die mensdom, veral soos dit in Christus tot volle vervulling gekom het, wys duidelik dat die vereiste 
is om geestelik in Hom ingeplant te wees deur die geloof in God se verlossingswerk in Hom. Dít bring die mens, manlik en vroulik, tot volle menswees en beeld-van-God-wees.

Soos die koms van die koninkryk saamtrek in God se lewendmakende werksaamheid in Christus se dood en opstanding, so benader die Skrif alles teosentries, insluitende die menslike lewe en dood (die "individuele geslagsregister"). Die psalms praat min oor die lewe na die dood, want hulle fokus op hulle verhouding met God self en laat die res met vertroue aan Hom oor (Helberg, s.a.:197). God se verbintenis met ' $n$ mens is lewend en lewegewend. Die teosentriese benadering van die Skrif kom ook duidelik uit in Christus se verrassende Skrifbewys oor die opstanding (Matt. 22:2332). God se verhouding met mense is so persoonlik dat as Hy Hom aan iemand verbind, dit 'n onverbreeklike persoonlike verbintenis vorm. "Hy is nie 'n God van dooies nie, maar van lewendes." Hierdie Skrifgedeelte wys ook dat God se persoonlike verhouding met 'n mens alles beheers en alle ander verhoudings, soos manlik en vroulik, relatief maak. Ná die dood trou mense nie meer nie, maar is hulle soos die engele.

\section{Die vrou se posisie in die nuwe bedeling}

Soos in die geslagsregister aan die begin, kom die vrou weer sterk op die voorgrond aan die einde van Matteus. Die opvallende hierin is dat God die vrou wat so gering geag was, die eerste getuie van Christus se opstanding laat wees (Green, 2000:313). Dit stem ooreen met Christus se eie optrede om as nederige sy taak te vervul.

Christus se opdrag aan die dissipels by sy hemelvaart (Matt. 28:1620 ) is daarop gegrond dat aan Hom "alle mag in die hemel en op die aarde" gegee is (Matt. 28:18; Dan. 7:14). Hierdie mag het Hy vroeër reeds besit, maar dit nie uitgeoefen nie. Hy het sy roeping dienend uitgeoefen. Sy dissipels sal steeds dienend moet optree totdat $\mathrm{Hy}$ weer kom (vgl. ook Breed et al., 2008:20 oor die uniekheid van die besondere dienste). Mense uit alle nasies moet nou dissipels van Christus gemaak word en in die Naam van die Vader en die Seun en die Heilige Gees gedoop word. Nou is, soos die profesie verkondig het (Jes. 49:6; Matt. 8:11-12; 21:43), die bande van partikularisme finaal verwyder. Dit geld ook van die geslagtelike bande (Gal. 3:28). Christus se "by-julle-wees" (Matt. 28:20) en die aard van die gesag wat sy dissipels in aansluiting by sy diens, dood en opstanding ontvang, is die vereiste toerusting om hierdie roeping uit te voer. Hulle ontvang die Woord en Gees van Christus wat dienend is, maar alle mag het. 
Hulle verkondig die andersoortige Koning, Priester en Profeet. Die konings, profete en priesters was net skaduagtig bemiddelend. Hy neem hulle plek in en bemiddel ten volle. Die gelowiges ontvang weer hulle regmatige plek as mens: beeld, verteenwoordiger van God as profeet, priester en koning. Hulle is nie meer onder 'n menslike profeet, priester en koning gestel nie, maar onder Christus se gesag, uitgeoefen deur sy Woord en Gees. Nou is hulle ook nie meer gestel onder 'n menslike bemiddelaar, soos 'n eggenoot of die man in die algemeen nie. Die vrou is trouens 'n volledige mens, volledig toegerus om te "regeer" soos die koninkryksregering in die nuwe bedeling dit vereis: om in dienende liefde vir God se gemeente op te tree en te sorg. Hierdie regering is nie soos menslike heerskappy wat mag, soos dié van 'n man, vereis nie, maar 'n koninkryksregering. Die Woord moet aan die woord gestel word en daarvolgens moet besluite geneem word.

\section{Samevatting en gevolgtrekking}

Die geboorte van Christus uit ' $n$ vrou, deur die Heilige Gees, sonder die toedoen van 'n man, is 'n vervulling van die Ou-Testamentiese beloftes. Tegelykertyd maak hierdie geboorte 'n einde aan die afdraande- en doodsgang van die mensdom deurdat Christus 'n mens van sondes verlos. In Hom is God by ons deur die Gees. Hy oorwin die vervreemding wat in die begin van die menslike geskiedenis, met die mens se sonde in die tuin van Eden, begin het, vervreemding tussen God en mens en tussen mense onderling. Die sonde het menswees en harmonie tot in die intiemste verhouding grondig versteur. Heerskappy is dikwels uitgeoefen deur dwang, soos in slawerny en in die miskenning van die vrou se volle menswees en beeld-van-God-wees.

Die mens word as beeld van God herskep en in 'n direkte persoonlike verhouding met Hom herstel. Christus is vir alle gelowiges, sonder onderskeid in stand of geslag, die Immanuel, God by ons. Heerskappy-voer oor ander, soos in manlike dominering oor die vrou en in die aardse koningskap en slawerny, maak plek vir diensbaar-wees. Die regering van God se kerk vra diensbaarheid, nie uiterlike heerskappy nie. Aan Christus is alle mag gegee, maar Hy oefen dit dienend uit. Veral sy kerk moet dienend regeer deur Hom as enigste Hoof te erken en van sy lewe, dood en opstanding te getuig soos dit in sy Woord vervat is. Daarvoor is 'n gelowige vrou net so toegerus as ' $n$ man. Daar is geen rede om haar van die regeerdiens in die kerk uit te sluit nie. 
Skrifgedeeltes wat die vrou blykbaar ondergeskik aan die man stel, moet benader word uit hulle agtergrond en in die lig van hierdie verlossingsaankondiging in Matteus. Nie alleen die hele boek Matteus nie, maar die hele Nuwe Testament as vervulling van die Ou Testament, word daardeur beheers.

\section{Addendum}

Breed, D.G., Janse van Rensburg, J.J.(Fika), Jordaan, G.J.C. 2008. Manlik en vroulik in die kerk: geslagtelikheid en die besondere dienste. Potchefstroom: Potchefstroomse Teologiese Publikasies.

Hierdie publikasie is die vrug van 'n studie saam met 'n aantal medewerkers en in opdrag van die Gereformeerde Teologiese Vereniging.

Die boek bespreek die volgende: kerkregtelike en kerkhistoriese perspektiewe, Skrifbeskoulike vertrekpunte, hermeneutiese vertrekpunte, eksegese en hermeneuse, Ou-Testamentiese Skrifgedeeltes - opsomming van Skrifgegewens, die vrou in die evangelies, eksegese en hermeneuse van ter sake Nuwe-Testamentiese Skrifgedeeltes. Dan word eksegetiese en hermeneutiese gevolgtrekkings gemaak en die implikasies gestel.

Hierdie deeglike studie gee 'n grondige en verantwoorde bespreking en gevolgtrekking van die ter sake elemente. Die studie sal veral die Gereformeerde Kerke in Suid-Afrika (GKSA) dien deur die benaderingswyse en deur die gevolgtrekking: "Geen Skrifdeel spreek hom direk en duidelik oor geslagtelikheid in die besondere dienste uit nie" (p. 49); "God se openbaring is nie bedoel om vir alle aangeleenthede 'n (volledige) antwoord te gee nie. Die gevaar bestaan dat die Skrif óórvra kan word ... In so 'n geval behoort kerke in sinode nie 'n besluit te neem wat één verstaansmoontlikheid sanksioneer en die ander as ketters verklaar nie" (p. 203); "Die verskille wat daar wel is, raak nie Skrifbeskoulike, eksegetiese en hermeneutiese vertrekpunte nie. Eerder is dit toe te skryf aan verskil in die beoordeling van die eksegetiese oortuigingskrag van die betrokke standpunte" (p. 205).

Die skrywers self verskil onderling. Een benadering is dat die man in die huwelik die hoof is, maar dat die kwessie rondom die vrou in die besondere dienste kultuurhistories is en dat ' $n$ vrou in alle besondere dienste mag dien. Die ander benadering is dat 'n vrou ook nie in die besondere dienste mag dien nie (p. 116-117, 131, 144-145, 
155). Volgens albei benaderings moet die vrou nie as minderwaardig beskou word nie (p. 79), sy het ook 'n regeeropdrag by die skepping ontvang (p. 69) en die hoofskap en/of diens moet dienend uitgeoefen word. "Alle dienswerk se hoofdoel is dat Christus se kurios-skap erken en gehoorsaam word" (p. 26-29).

By al die waardering vir die boek bevat dit die volgende leemte: die koninkryksperspektief word wel as vertrekpunt en aanknopingspunt gestel (p. 48-49), maar word nie uitgewerk nie. Daar ontbreek 'n uiteensetting van die ingrypende, herskeppende openbaringshistoriese gebeurtenis van Jesus Christus se geboorte as vervulling van die Ou-Testamentiese verwagtings. Hierdie gebeurtenis is so ingrypend dat die Bybel van vroeg in die kerkgeskiedenis af as tweeledig aangedui word, naamlik as Ou Testament en Nuwe Testament. In vergelyking met die interimperiode vanaf Abraham, oor Dawid en oor die Babiloniese ballingskap tot by die koms van Christus, bring die vervulling deur Christus 'n ingrypende verandering in die manier waarop God sy koninkryk laat kom. Dit raak ook veral sy regering van sy nuwe volk, die kerk wat nou heeltemal deur diens beheers moet word. Wat dit vir die vrou inhou, word in die bygaande artikel bespreek.

\section{Geraadpleegde bronne}

ANDERSON, J.C. 1983. Matthew: gender and reading. Semeia, 28:3-27.

BIRD, P.A. 2001. Theological anthropology in the Hebrew Bible. (In Perdue,

L.G., ed. The Blackwell companion to the Hebrew Bible. Oxford: Blackwell. p. 258-275.)

BREED, D.G., JANSE VAN RENSBURG, J.J., JORDAAN, G.J.C. 2008. Manlik en vroulik in die kerk: geslagtelikheid en die besondere dienste. Potchefstroom: Potchefstroomse Teologiese Publikasies.

BRUEGGEMANN, W. 1982. Genesis. Atlanta: John Knox. (Interpretation: A Bible commentary for teaching and preaching.)

BRUEGGEMANN, W. 1997. Theology of the Old Testament. Minneapolis: Fortress.

CHILDS, B.S. 1979. Introduction to the Old Testament as Scripture. London: SCM.

CHILDS, B.S. 1986. Old Testament theology in a Biblical context. Philadelphia: Fortress.

DE VAUX, R. 1968. Ancient Israel: its life and institutions. London: Darton.

DU PLOOY, A. LE R. 1982. Kerkverband: 'n Gereformeerd-kerkregtelike studie. Potchefstroom: PU vir CHO. (Th.D.-proefskrif.)

FLOOR, L. 1981. Die evangelie van die koninkryk: 5 aspekte. Pretoria: NG Kerkboekhandel.

GREEN, M. 2000. The message of Matthew. Leicester: InterVarsity. (The Bible speaks today.)

GROSHEIDE, F.W. 1953. Commentary on the first epistle to the Corinthians. Grand Rapids: Eerdmans. 
HAGNER, D.A. 1993. Matthew 1-13: Word Biblical commentary. Dallas: Word Books.

HELBERG, J.L. s.a. The Lord reigns. Potchefstroom: PU for CHE.

HELBERG, J.L. 2005. Geïntegreerdheid van die psalms volgens die verband tussen Psalm 1 en 2 en die res van die psalms. In die Skriflig, 39(4):673694.

HOLWERDA, B. 1971. Historia revelationis veteris Testamenti 1: Oudtestamentische voordrachten. Kampen: Copiëerinrichting v.d. Berg.

KEEL, O. 1997. The symbolism of the Biblical world: ancient near Eastern iconography and the book of Psalms. Winona Lake: Eisenbrauns.

KRATZ, R.G. 2003. Der Mythos vom Königtum Gottes in Kanaan und Israel. Zeitschrift für Theologie und Kirche, 100:149-162.

KRAUS, H-J. 1972. Psalmen 1. Neukirchen-Vluyn: Neukirchener Verlag. (Biblischer Kommentar Altes Testament, 15/1.)

KROEZE, J.H. 1967. Die tuin van Eden: Genesis 2 en 3 aandagtig gelees. Pretoria: NG Kerkboekhandel.

KÜNG, H. 2005. Women in Christianity. London: Continuum.

LEVINE, A-J. 1998. Matthew. (In Newsom, C.A. \& Ringe, S.H., eds. Women's Bible commentary. Expanded edition. Louisville: Westminster. p. 339-349.)

LUZ, U. 1985. Das Evangelium nach Matthäus. Bd. 1: Mt 1-7. Neukirchen: Benziger Verlag. (Evangelisch-Katholischer Kommentar zum Neuen Testament.)

MARSHALL, I.H. 1999. The pastoral epistles: Edinburgh: Clark. (A critical and exegetical Commentary.)

MITCHELL, D.C. 1997. The message of the Psalter: an eschatological programme in the book of Psalms. (JSOT supplement series, 252.)

NIDITCH, S. 1998. Genesis. (In Newsom, C.A. \& Ringe, S.H., eds. Women's Bible commentary. Expanded edition. Louisville: Westminster. p. 13-29.)

PEELS, H.G.L. 2007. God en geweld in het Oude Testament. Apeldoorn: Theologische Universiteit Apeldoorn.

RIDDERBOS, H.N. 1995. Matthew. Grand Rapids: Zondervan. (The Bibles student's commentary.)

RIDDERBOS, J. 1955. De Psalmen. 1: Psalmen 1-41. Kampen: Kok. (Commentaar op het Oude Testament.)

RODD, C.S. 2001. Glimpses of a strange land: studies in Old Testament Ethics. Edinburgh: Clark.

ROGERSON, J.W. 1993. The enemy in the Old Testament. (In Auld, A.G., ed. Understanding poets and prophets: essays in honour of George Wishart Anderson. p. 284-293.) (JSOT. supplement series,157.)

SCHOTTROFF, W. 1971. jd' erkennen. (In Jenni, E. \& Westermann, C., Reds. Theologisches Handwörterbuch zum Alten Testament. 1. München: Kaiser Verlag. S. 682-702.)

SHEPPARD, G.T. 1991. "Enemies" and the politics of prayer in the book of Psalms. (In Jobling, D., Day, P.L., Sheppard, G.T., eds. The Bible and the politics of exegesis: essays in honour of Norman K. Gottwald on his sixtyfifth birthday. Cleveland: Pilgrim. p. 61-82.)

SPOELSTRA, B. 2007. Die vraag na gesag op Sinode 1964. Die Kerkblad, 110(3205):27-29, 39.

VAN BRUGGEN, J. 1990. Matteüs: het evangelie voor Israël. Kampen: Kok.

VAN SELMS, A. 1967. Genesis. Nijkerk: Callenbach. (De prediking van het Oude Testament.) 
VAN WYK, J.H. 2008. Spanning in die kerk. Die Kerkblad, 110(3207):6-7.

VON RAD, G. 1966. Genesis. London: SCM. (The Old Testament library.)

WEBER, B. 2006. Psalm 1 and its function as a directive into the Psalter and towards a Biblical theology. Old Testament essays, 19(1):237-260.

WEISER, A. 1959. Die Psalmen. Göttingen: Vandenhoeck \& Ruprecht. (Das Alte Testament Deutsch, 14/15.)

WESTERMANN, C. 1974. Genesis. Neukirchen Vluyn: Neukirchenener Verlag. (Biblisicher Kommentar Altes Testament.)

WOLFF, C. 1996. Der erste Brief des Paulus an den Korinther. Berlin: Evangelische Verlagsanstalt. (Theologischer Handkommentar zum Neuen Testament.)

\section{Kernbegrippe:}

besondere kerklike dienste, vrou

vervulling - Ou Testament, Christus

\section{Key concepts:}

church offices, woman

fulfilment - Old Testament, Christ 
